\title{
フッ素系ガスによる薄膜堆積装置のクリーニング
}

\author{
毛利 勇 $^{*}$, 藤井 正 ${ }^{*}$, 小林義幸 ${ }^{* *}$, 早川誠而 ${ }^{* *}$
}

\section{Plasmaless Dry Cleaning of CVD System with Fluorine-Containing Gases}

\author{
Isamu MOURI*, Tsukasa FUJII*, \\ Yoshiyuki KOBAYASHI** and Seiji HAYAKAWA***
}

Key Words : Fluoridation, Environmental Protection, $\mathrm{ClF}_{3}, \mathrm{HF}, \mathrm{NF}_{3}$

フッ素系ガスの化学反応によるクリーニングは配管を含めた装置全体をクリーニング可能な方法であ る。本報告では, $\mathrm{ClF}_{3}, \mathrm{HF}, \mathrm{F}_{2}$ 添加 $\mathrm{NF}_{3}$ を用いた新規なクリーニング法について述べる。

\section{1. 緒言}

LSI，TFTを始めとする薄膜デバイス製造工程では 種々の物質がシリコンウエハなどの基板上に成膜されて いるが，成膜を行うと反応器内表面や配管内表面にも膜 や反応副生成物が堆積する。これらの堆積物はプロセス パラメータの変動やパーティクル発生の要因となるため 随時クリーニングする必要がある。

従来, これら不要な堆積物のクリーニングは, サンド ブラスティングなどの物理的方法, フッ化水素酸や水酸 化ナトリウム水溶液などを用いる湿式法で行われてきた。 しかし，これらの方法は装置材料へのダメージが大きく， さらに，装置の解体・洗浄・組立を必要とするため時間 と労力がかかり, 装置稼働率を著しく低下させる原因と なっている。これら従来行われてきたクリーニング法と 比較してフッ素系ガスによるガスクリーニングは反応装 置内にガスを導入するだけでよく非常に効率的である。

ガスクリーニングは，プラズマクリーニングとプラズ マレスクリーニングに大別できる。プラズマクリーニン グは, $\mathrm{SF}_{6}, \mathrm{CF}_{4}, \mathrm{C}_{2} \mathrm{~F}_{6}$ や $\mathrm{NF}_{3}$ をプラズマで活性化さ せ, 発生したFラジカル（もしくはFイオン）でクリー ニングする方法である。この方法むしくは使用されてい

*セントラル硝子(侏) 化学研究所（テ755 山口県宇部市大字 沖宇部 5253)

Chemical Res. Center, Central Glass Co., Ltd. (5253, Okiube, Ube-shi, Yamaguchi 755)

**セントラル化学㨀術課（テ210 神奈川県川崎市川崎区 浮島町 10-2)

Technical Planning Section, Central Chemical Co., Ltd. (10-2, Ukishima-cho, Kawasaki-ku, Kawasaki-shi, Kanagawa 210)

***山口大学 農学部（†753 山口県山口市吉田1677-1）

Fac. of Agriculture, Yamaguchi Univ. (1677-1, Yoshida, Yamaguchi-shi, Yamaguchi 753)
るガスには以下のような問題が指摘される。

1）プラズマを発生させる機構を備えていることが必 要であるため適応可能な装置が限定される。

2 ）イオン衝撃による装置材料に与える損傷が大きい。

3 ）使用するガス種によってはクリーニング時に 2 次 污染物を生成する場合がある。

4) プラズマ中あしくは近傍しかクリーニングできず, 配管内は全くクリーニングできない。

5 ) $\mathrm{SF}_{6}$ やフロン系のガスは大気中での寿命が長く, かつ, GWPが高いため環境への悪影響が緐念さ れる。

6 ）比較的安定なガスを使用するため未反応排ガスの 処理が困難である。

これらの問題を解決する方法としてフッ素系ガスによ る熱化学反応を利用したプラズマレスクリーニング法が ある。このクリーニング法には高反応性フッ化物ガスを 用いるが，なかでも $\mathrm{ClF}_{3}$ は半導体製造工程における多 結晶シリコンやタングステン成膜装置の in-situ クリー ニングガスとして需要が高まっている。横型熱 CVD装 置への $\mathrm{ClF}_{3}$ クリーニング導入の効果は, Doped poly$\mathrm{Si}$ の場合, パーティクル数が $60 \%$, メンテナンス時間 が $21 \%$ 低減可能であることが報告されている ${ }^{1) 。 ~}$

以下, $\mathrm{ClF}_{3}, \mathrm{HF}, \mathrm{F}_{2}$ 添加 $\mathrm{NF}_{3}$ のクリーニグガスと しての応用を中心に述べる。

\section{2. 実験方法}

エッチング試験および装置材料の耐食試験は, $\mathrm{Ni}$ 製 ホットウオール型反応装置と石英製チャンバに $\mathrm{Ni}$ 製ヒー タを備えたコールドウオール型装置を使用した。エッチ ング前後の膜厚測定はXRFを用いて行った。粉体やカ レット状の試料とフッ化物ガスとの反応速度の測定には 


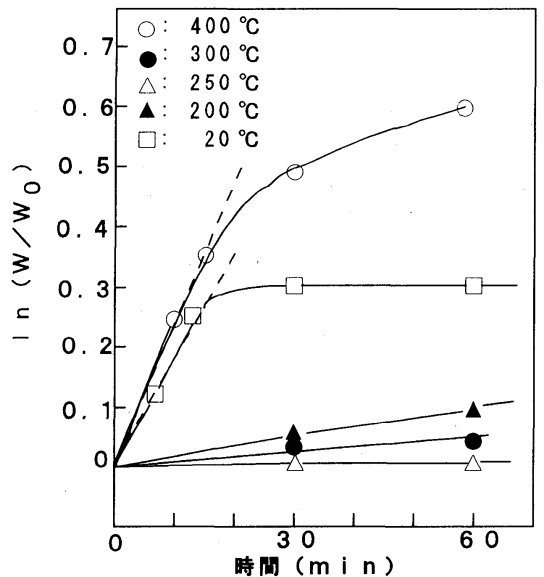

図 $1 \mathrm{ClF}_{3}$ 雾井気下における HDIG の TG 曲線 ガス圧力 : 760Torr ガス濃度 : $\mathrm{ClF}_{3} 100 \mathrm{vol} \%$ $\mathrm{W}_{0}$ : 初期重量 $(100 \mathrm{mg})$ $\mathrm{W}$ : 暴露後重量

耐フッ素熱重量分析装置を使用した。クリーニング前後 の試料はXRF，XRD，SEMを用いて解析した。試料 とフッ化物ガスとの気体状の反応生成物の分析は FTIRスペクトロメータ，紫外可視分光光度計，ガスクロ マトグラフを使用した。

\section{3. $\mathrm{ClF}_{3}$ によるガスクリーニング}

$\mathrm{ClF}_{3}$ は強力なフッ素化剤として知られているが，プ ラズマレスクリーニングガスとして使用するためには, (1) 装置材料の $\mathrm{ClF}_{3}$ に対する耐食性 (2) 装置材料の耐食 条件範囲での堆積物に対するエッチング速度 (3) 排ガス 処理条件（反応生成物の同定） (4) 可燃性ガスとの混食 危険性を明らかにする必要がある。

\section{1 装置材料の $\mathrm{ClF}_{3}$ に対する耐食性}

3. 1.1 等方性高密度黒鉛 $(\mathrm{HDIG})^{2)}$

等方性高密度黒鉻はシリコンウエハを保持するサセプ 夕や装置内の種々の部品として広範に使用されている。

図 1 は, シリコンウェハのサセプタとして使用されて いる HDIGをカッティングした試料の $\mathrm{ClF}_{3}$ 雾囲気下 における TG曲線である。この TG曲線の直線部の傾き から得た見かけ上の反応速度定数 $(k)$ と雾囲気ガス温

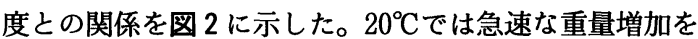

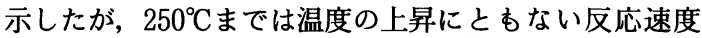
は隇少した。この結果から $250^{\circ} \mathrm{C}$ 以下の温度領域では, 低温でより安定な $\mathrm{HDIG}$ と $\mathrm{ClF}_{3}$ との首間化合物が生 成するあのと考えられる（式(1)）。

$$
x \mathrm{C}+\mathrm{ClF}_{3} \rightarrow \mathrm{C} x \mathrm{ClF}_{3}
$$

一方, $250^{\circ} \mathrm{C}$ 以上の温度領域ではフッ化黒鉿 $\left((\mathrm{CnF})_{x}\right.$, $n \geqq 1 ）$ の生成が起こるため温度の上昇にとあない反応

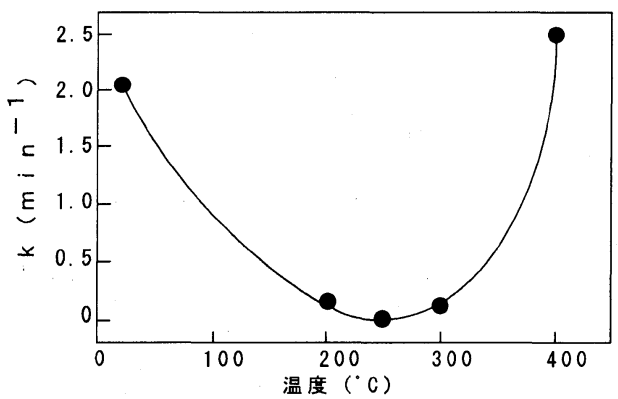

図 $2 \mathrm{ClF}_{3}$ と HDIG との反応における反応速度定数とガス温 度との関係

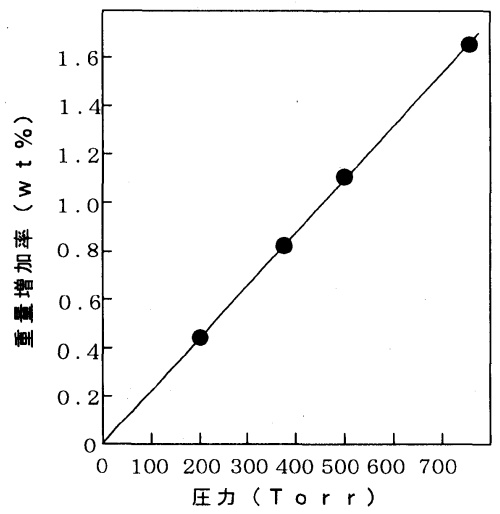

图 $3 \mathrm{ClF}_{3}$ 雾囲気下における HDIG の重量増加率とガス圧力 との間倸

ガス温度 : $300\left({ }^{\circ} \mathrm{C}\right)$

ガス濃度 : $\mathrm{ClF}_{3}$ 100vol\%

表 1 HDIG の重量増加と $\mathrm{ClF}$ 濃度との関係 (系内圧力 : 500Torr)

\begin{tabular}{lcll}
\hline ガス温度 $\left({ }^{\circ} \mathrm{C}\right)$ & $\mathrm{C} \mid \mathrm{F}_{3}$ 浱度 $(\mathrm{vol})$ & 暴露時間 $(\mathrm{Hr})$ & 重量增加率 $(\mathrm{wt} \%)$ \\
\hline 200 & 1 & 0.5 & $\mathrm{ND}$ \\
200 & 10 & 0.5 & $\mathrm{ND}$ \\
200 & 100 & 0.5 & 2.612 \\
250 & 1 & 0.5 & $\mathrm{ND}$ \\
250 & 10 & 0.5 & $\mathrm{ND}$ \\
250 & 100 & 0.5 & 0.800 \\
250 & 1 & 7.0 & 0.006 \\
300 & 1 & 0.5 & ND \\
300 & 10 & 0.5 & $\mathrm{ND}$ \\
300 & 100 & 0.5 & 1.114 \\
\hline
\end{tabular}

*ND means not detected.

速度が増加する。また， $200^{\circ} \mathrm{C}$ から $300^{\circ} \mathrm{C}$ の温度領域で は低濃度の $\mathrm{ClF}_{3}$ に暴露してあ層間化合物むフッ化黒鉛 の生成もほとんど起こらなかった（表 1)。図 3 に $300^{\circ} \mathrm{C}$ の温度条件下で HDIGを暴露し，重量増加が止まった 後の試料の重量増加率と $\mathrm{ClF}_{3}$ ガス圧力との関係を示し た。この結果は, $\mathrm{HDIG}$ の損傷が $\mathrm{ClF}_{3}$ ガス圧力に比例 
することを表わしている。

以上の結果から, HDIGのクリーニングは $250^{\circ} \mathrm{C}$ 前後 の温度でクリーニングする必要があり, 圧力条件は堆積 している物質に対するエッチング速度からプロセス条件 を勘案しできるだけ低い圧力で行う必要があることがわ かる。また，クリーニング後に残留する $\mathrm{F}, \mathrm{Cl}$ につい ては加熱処理を行うことにより実用上問題ないレベルま で低減可能である。

現在では黒鉛に代えてグラッシーカーボンを用いてい る装置あある。グラッシーカーボンの場合は層間化合物 の生成は認められず，その種類にもよるが $300^{\circ} \mathrm{C}$ 以下の 温度条件下でなら実用上使用可能である。

\section{1. 2 ステンレスの耐食性}

$\mathrm{ClF}_{3}$ に対してマグネシゥム, アルミニウム, 銅, ニッ ケル, 鉄は表面にフッ化不動態膜を形成しそれ以上の反 応を押さえるが高温ではさらにフッ素化される ${ }^{3)}$ 。 150 ${ }^{\circ} \mathrm{C}$ 以上の温度でステンレス鋼（SUS 316L）を $\mathrm{ClF}_{3}$ で 暴露すると表面に粒子状の物質が生成し腐食する。 230 ${ }^{\circ} \mathrm{C}$ で $\mathrm{ClF}_{3}$ に暴露して腐食させたステンレス基板表面を $\mathrm{XRD}$ で分析すると $\mathrm{FeF}_{3}$ の生成が確認できるが塩化 物は検出できなかった。 $\mathrm{F}_{2}$ による鉄系金属の腐食は, $\mathrm{FeF}_{2}$ がフッ素化され $\mathrm{FeF}_{3}$ が生成する際に両者の密度 差から膜の亀裂やはく離が生じることで進行する。また, 式 (2) の反応は $265^{\circ} \mathrm{C}$ 以上温度で起こり,この温度以 下であればステンレスの腐食は起こらないことが知られ ている ${ }^{4)}$ 。

$\mathrm{FeF}_{2}+1 / 2 \mathrm{~F}_{2} \rightarrow \mathrm{FeF}_{3}$

熱重量分析装置を用いて $\mathrm{FeF}_{2}$ の $\mathrm{ClF}_{3}$ によるフッ素化 を行ったところ $250^{\circ} \mathrm{C}$ から重量増加を起こし $\mathrm{FeF}_{3}$ を生 成した (式 (3))。ところが, $\mathrm{F}_{2}$ の場合とは異なりステン レス（SUS 316）の腐食は $250^{\circ} \mathrm{C} よ り$ 低い温度で起こる。

$\mathrm{ClF}_{3}$ による腐食メカニズムはまだ明らかになってお らず，今後さらに検討を進めていく必要がある。

$\mathrm{FeF}_{2}+1 / 2 \mathrm{ClF}_{3} \rightarrow \mathrm{FeF}_{3}+1 / 2 \mathrm{ClF}$

なお, フェライト系ステンレスはオーステナイト系ス テンレスより耐食性が劣り, SUS 430 の場合 $90^{\circ} \mathrm{C}$ 以上 では腐食する。

\section{3. $2 \mathrm{ClF}_{3}$ による薄膜材料のエッチング}

製品の生産性の向上を図る場合クリーニングプロセス に要する時間はできる限り短時間であることが望まれる。 クリーニングに要する時間を試算するうえでエッチング 速度の测定は必要である。まず, $\mathrm{ClF}_{3}$ による $\mathrm{Si}$ のエッ チング特性について述べる。

Ibbotson らは $\mathrm{ClF}_{3}$ による単結晶シリコンのエッチ

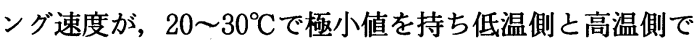
各々次式で表わされると報告している（式(4), 式(5)）。 。 低温側

$$
R_{\mathrm{L}}=1.63 \times 10^{-23} n_{\mathrm{CIF}_{3}} T^{1 / 2} \exp (11.0 / k T) \cdots \cdots(4)
$$

表 $2 \mathrm{ClF}_{3}$ とポリシラン粉との反応における反応生成物

\begin{tabular}{|c|c|}
\hline $\mathrm{C} \mid \mathrm{F}_{3} / \mathrm{a}-\mathrm{S} \mathrm{i}_{2} \mathrm{H}_{3}(\mathrm{~mol} / \mathrm{mol})$ & 反応生成物 \\
\hline$\sim 3.6$ & $S$ iF $, H F, H C I, C I=$ \\
\hline 3. $6 \sim 4.7$ & $S$ IF:HF,CI= \\
\hline 4. $7 \sim 5.5$ & $S \mathrm{SF}_{4}, \mathrm{HF}, \mathrm{Cl}=\mathrm{C} \mid \mathrm{F}$ \\
\hline $5.5 \sim$ & $S i F_{\triangleleft}, H F, C \backslash F$ \\
\hline
\end{tabular}

\section{高温側}

$$
\begin{aligned}
& R_{\mathrm{H}}=1.60 \times 10^{-12} n_{\mathrm{ClF}_{3}} T^{1 / 2} \exp (-4.1 / k T) \cdots \cdots(5) \\
& R_{\mathrm{L}, \mathrm{H}}: \text { エッチング速度 }(\mathrm{A} / \mathrm{min}) \\
& n_{\mathrm{ClF}}: \mathrm{ClF}_{3} \text { の密度 }\left(\mathrm{cm}^{-3}\right) \\
& k: \text { ボルッマン定数 }\left(1.987 \times 10^{-3}\left(\mathrm{kcal} / \mathrm{mole} /{ }^{\circ} \mathrm{K}\right)\right. \\
& T: \text { 基板温度 }\left({ }^{\circ} \mathrm{K}\right)
\end{aligned}
$$

低温側では $\mathrm{ClF}_{3}$ ガスの吸着確率が高くなるためエッ チング速度が極小值を有すると考えられている。また, 斎藤らは $40^{\circ} \mathrm{C}$ 付近で極小值を持ち, $40 \sim 130^{\circ} \mathrm{C}$ の範囲で は Ibbotson らの測定結果と同様の活性化エネルギを持 つが $130^{\circ} \mathrm{C}$ 以上では活性化ェネルギが高くなると報告し ている ${ }^{6)}$ 。

$\mathrm{ClF}_{3}$ と堆積物との反応機構は供給量, 温度によって 異なる ${ }^{7)}$ 。室温での $\mathrm{ClF}_{3}$ とポリシラン粉 $\left(\left(\mathrm{a}-\mathrm{Si}_{2} \mathrm{H}_{3}\right)_{n}\right)$ の混合 mol 比と検出される反応生成物との関係を表 2 に記した。室温下では検出されなかったが，高温（600 $\left.{ }^{\circ} \mathrm{C}\right)$ で多結晶シリコンをクリーニングした排ガス中に $\mathrm{SiCl}_{4}$ の生成を確認している。このことは, 実際のクリー ニングプロセスではSiに対してェッチング速度が比較 的遅いことが知られている $\mathrm{ClF}, \mathrm{Cl}_{2}$ によるエッチング あ起こっていることを示している。したがって, 排ガス 処理はクリーニング条件を勘案したうえで適切な条件を 決定する必要がある。

次に, $\mathrm{a}-\mathrm{Si}$ : H並びに $\mathrm{a}-\mathrm{SiN}_{x}: \mathrm{H}$ 成膜用プラズマ CVD装置への適用について述べる。これらの装置のク リーニング対象物は, 硝子基板を保持するサセプタ上や 反応器内壁に堆積した膜および主に排気系配管内に堆積 するポリシラン粉 (反応副生成物) である。現状, これ らの装置では $\mathrm{C}_{2} \mathrm{~F}_{6}$ と $\mathrm{O}_{2}$ の混合ガスや $\mathrm{NF}_{3}$ によるプラ ズマクリーニングが行われている。しかし，この方法で は電極の裏面や配管内までをクリーニングすることは困 難である。また, $\mathrm{a}-\mathrm{SiN}_{x}: \mathrm{H}$ をプラズマクリーニング すると 2 次污染物である $\left(\mathrm{NH}_{4}\right)_{2} \mathrm{SiF}_{6}$ を生成し配管内 に堆積する。一方, $\mathrm{ClF}_{3}$ は, $\mathrm{a}-\mathrm{Si}: \mathrm{H}$ に対しては高い エッチング速度を有し (図 4 ), ポリシラン粉も速やかに 除去可能である。しかし，a-SiN $\mathrm{x}$ : Hに対するエッチ ング速度は比較的遅く, 基板保持用サセプタ材料として 一般的に使用されている SUS 430 の耐食条件温度では 十分なエッチング速度を確保することは難しい（図４）。 この場合, HFを添加することでエッチング速度を高め ることができる。図5に HFの添加量とエッチング速度 


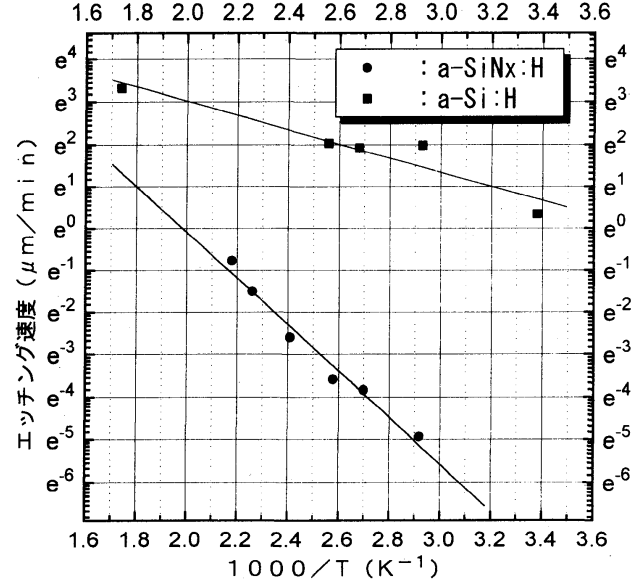

図 $4 \mathrm{ClF}_{3}$ に対する $\mathrm{a}-\mathrm{Si}: \mathrm{H}, \mathrm{a}-\mathrm{SiN}_{\mathrm{x}}: \mathrm{H}$ のエッチング速度 の温存依存性

エッチング条件

$\mathrm{a}-\mathrm{Si}: \mathrm{H}$

$\mathrm{ClF}_{3}$ 濃度 : $10 \mathrm{vol} \%$, 圧力 : $240 \mathrm{Torr}$

$\mathrm{a}-\mathrm{SiN}_{\mathrm{x}}: \mathrm{H}$

$\mathrm{ClF}_{3}$ 濃度 : 10vol\%, 圧力 : 700Torr

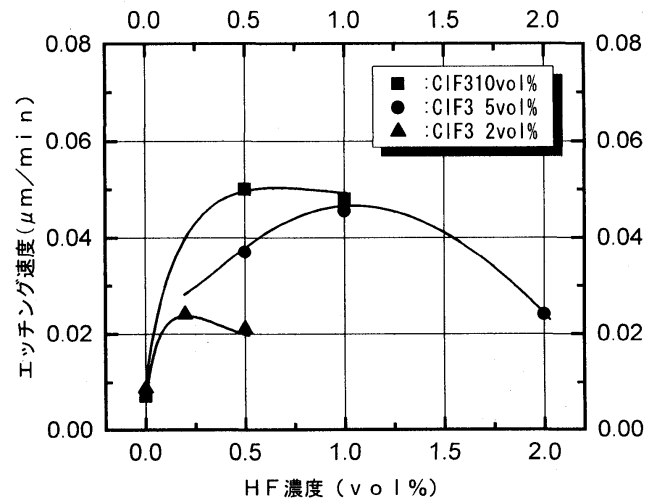

図 $5 \mathrm{ClF}_{3}$ と $\mathrm{HF}$ の混合ガスによる $\mathrm{a}-\mathrm{SiN}_{\mathrm{x}}: \mathrm{H}$ のエッチング 速度

エッチング条件

圧力 : $700 \mathrm{Torr}$, 温度 : $70^{\circ} \mathrm{C}$

との関係を示した。HFの添加量に対してェッチング速 度は極大值を有するが, これは HFの基板表面でのカバ レッジが飽和すると $\mathrm{ClF}_{3}$ の反応確率が低下するためと 考えられる。なお, HFを添加してあステンレスの耐食 性に影響しないことは確認している。

その他の材料として TiNについて述べる（図6）。こ の反応では比較的昇華点が高い $\mathrm{TiF}_{4}\left(284^{\circ} \mathrm{C}\right)$ を生成し, $\mathrm{ClF}_{3}$ 分圧を 14Torr から70Torrに上げてもエッチング 速度は高くならなかった。このことは, 基板表面から気 相への $\mathrm{TiF}_{4}$ の拡散速度がェッチングを律速しているこ

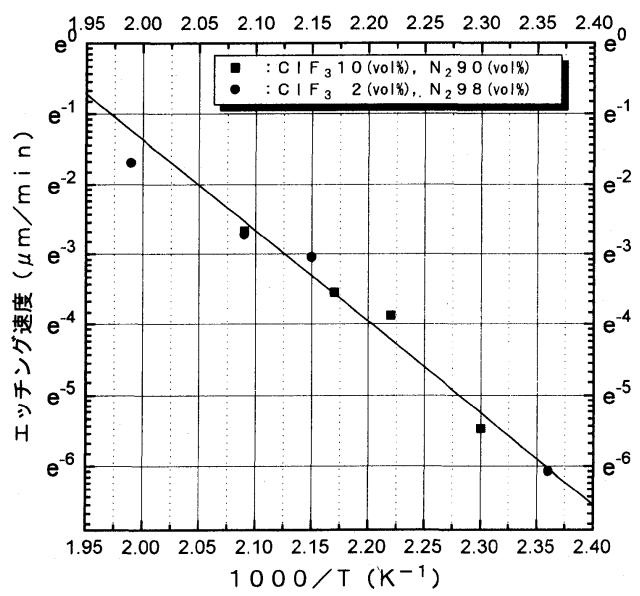

図 $6 \mathrm{ClF}_{3}$ 算囲気下における $\mathrm{TiN}$ のエッチング速度の温度依存 性 エッチング条件

圧力 : 700Torr

とを示している。また, 厚く $\mathrm{TiN}$ が堆積した装置部品 のクリーニングを行うと表面にフッ化物層ができエッチ ングが進行しない場合がある。 Ti 系, Ta系化合物のよ うに高昇華点（もしくは高沸点化合物）を生成する系に おいては反応器, 配管を十分に加熱しておき, 生成物を トラップで捕集する必要がある。

\section{3 可燃性ガスとの混合危険性}

CVD反応においては $\mathrm{SiH}_{4}$ を始めとする可燃性ガス が使用されている。 $\mathrm{SiH}_{2} \mathrm{Cl}_{2}, \mathrm{SiH}_{4}, \mathrm{TEOS}, \mathrm{NH}_{3}$, $\mathrm{H}_{2}$ および $\mathrm{CH}_{4}$ の $\mathrm{N}_{2}$ 希釈ガスと $\mathrm{ClF}_{3}$ との混合危険性 について大谷, 李らにより報告されており, $\mathrm{SiH}_{2} \mathrm{Cl}_{2}$, $\mathrm{SiH}_{4}, \mathrm{TEOS}, \mathrm{NH}_{3}$ とは燃焼範囲内のすべての組成 で自然発火すると述べられている ${ }^{8) ~ 10) 。 こ の こ と は, ~}$ CVD反応で使用される他の支燃性ガスと比較して, 爆 発危険性の観点からは安全であることを示している。

\section{HFによるガスクリーニング}

半導体プロセスではTEOSを原料とした熱 CVDで $\mathrm{SiO}_{2}$ が成膜されている。この CVD装置の排気系配管 内には TEOSの熱分解課程における中間体が多量に堆 積する。この堆積物を $\mathrm{ClF}_{3}$ や $\mathrm{F}_{2}$ でクリーニグすると 微量のパーティクル $\left(\mathrm{SiO}_{2}\right)$ が生成し, 反応器内のパー ティクル量增加の原因となる。ところが，HFガスを用 いるとパーティクルを生じることなくクリーニングでき

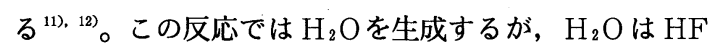
のイオン化を促し反応速度の上昇に寄与する。しかし, 液化すると HFを吸収しフッ化水素酸による金属腐食を 起こすためクリーニング条件の設定を慎重に行わなけれ ばならない。また, HFは非化学量的組成のシリコン酸 
化物に対してあ優れたクリーニング性能を示すことから, 今後, 重要なクリーニングガスになりうると考えられる。

\section{5. $\mathbf{F}_{2}$ 添加 $\mathrm{NF}_{3}$}

$\mathrm{NF}_{3}$ に $\mathrm{F}_{2}$ を添加することで $\mathrm{NF}_{3}$ 単体の場合に比べ て優れた機能を付加することができる。すなわち，(1) エッチング速度を大きく増加させることができるためプ ラズマレスクリーニングあ可能である (2) 強い支燃性を 有する $\mathrm{F}_{2}$ の効果で可燃性ガスとの混合による爆発危険 性を低減させることができる (3) 配管内の堆積物むクリー ニングできる。装置材料に対するダメージも比較的小さ いため高耐食性の装置材料への変更の必要がなく, 既設 の CVD装置や現状 $\mathrm{NF}_{3}$ プラズマクリーニングを導入 している装置のクリーニングに特に有効であると考えら れる。

\section{6. 結言}

$\mathrm{ClF}_{3}$ は半導体プロセスに扔ける多結晶シリコン, 夕 ングステンシリサイドの CVD装置やアモルファス感光 体の製造プロセスへの導入が積極的に進められている。 また, $\mathrm{F}_{2}$ 添加 $\mathrm{NF}_{3}$ や $\mathrm{HF}$ あ半導体などのプロセスに導 入され始めている。プラズマクリーニングではラジカル が到達できない箇所のクリーニングはできなかったが, プラズマレスクリーニングは, 反応器, 排気系配管およ び真空ポンプ内までクリーニング可能な方法であり，今 後もその応用範囲は広がって行くあのと考えられる。

\section{謝 辞}

原稿作成に協力して下さった中川主席研究員, 喜田主 席研究員, 田村所員に感謝する。

(1996-4-1＼cjkstart受理）

\section{文献}

1) 高橋広成 ; サイエンスフォーラム講演予稿集（「半導体製 造ラインにおける次世代ウエハ污染制御之除害設備対策」), 3-1-1 (1995)

2) I. Mouri, T. Fujii, Y. Kobayashi ; Proc. of 7th Regular Meeting of Japanese-Soviet Fluorine Chemists

3 ) 渡辺信淳 ; フッ素化学と工業 ( I ), p. 52（化学工業社, 1973)

4) 大見忠弘, 新田雄久; フッ素化学, p.95（リアライズ社, 1991)

5 ) D. E. Ibbotoson, J. A. Mucha, D. E. Flamm ; J. Appl. Phys., 56 (10), 15, 2939 (1984)

6 ) 斎藤洋司, 山岡 修, 吉田 明; 電子情報通信学会誌, 13 , SDM 89- 3 (1990)

7 ) 毛利 勇, 藤井 正, 小林義幸 ; 第13回フッ素フォーラム 資料, $13-5$ (1992)

8 ) S. G. Lee, H. Ohtani, Y. Uehara, M. Aramaki ; J. Loss Prev., 5, (3), 192 (1992)

9 ）李 相坤, 榎本隆光, 大谷英雄, 上原陽一; 燃焼の化学之 技術， 1，129 (1993)

10）李 相坤, 大谷英雄, 上原陽一 ; 安全工学, 33, 2 (1994)

11) I. Mouri, T. fujii, Y. Kobayashi, N. Nakagawa, Y. Kita ; 14th Int. Sym. on Fluorine Chemistry, 1 A 03, 3 (1994)

12）藤井 正, 毛利 勇, 中川伸介, 小林義幸 ; 春季応用物理 学会講演予稿集, $30 \mathrm{aC} 11 / \mathrm{II}$, p. 783 (1995) 